\title{
Severity levels of physical punishment of children/adolescents: cluster analysis
}

\author{
Níveis de gravidade da punição física de \\ crianças/adolescentes: análise de clusters
}

\author{
Roberta Noronha AZEVEDO ${ }^{1}$ iD) 0000-0002-3893-8112 \\ Marina Rezende BAZON ${ }^{1}$ (ID) 0000-0002-8037-8710
}

\begin{abstract}
Physical punishment - corporal punishment - of children/adolescents is highly prevalent. The objective of this study was to verify if, in a sample of parents/caregivers, there would be subgroups that would differentiate themselves regarding the behavior of physically punishing the children, in terms of modalities, frequency, body parts of the child affected, and presence of parental anger in the act of punishing, denoting severity levels associated with differences in the psychosocial variables pointed out in the literature as risk factors for physical abuse. A quantitative approach was adopted, with a cross-sectional design and cluster method. The study included 87 parents/caregivers who practice physical punishment. The analyses indicated the existence of three clusters that differed in the level of severity of corporal punishment and some of the psychosocial variables, denoting the importance of developing services/programs to cope with violence against children/adolescents and specific psychosocial intervention strategies.
\end{abstract}

Keywords: Child abuse; Family relations; Punishment; Social services.

\section{Resumo}

A punição física - castigos corporais - de crianças/adolescentes é altamente prevalente. O objetivo deste estudo foi verificar se em uma amostra de pais/cuidadores existiriam subgrupos que se diferenciariam quanto ao comportamento de punir/castigar fisicamente os filhos. As modalidades analisadas foram de frequência com que a punição ocorria, de partes do corpo da criança que se punia e de presença de sentimento de irritação/raiva durante o castigo físico, denotando

\footnotetext{
1 Universidade de São Paulo, Faculdade de Filosofia, Ciências e Letras de Ribeirão Preto, Departamento de Psicologia. Av. Bandeirantes, 3900, 14040-901, Ribeirão Preto, SP, Brasil. Correspondence to: M.R. BAZON. E-mails: <mbazon@ffclrp.usp.br>, <rn_azevedo@yahoo.com.br>.

Article based on the dissertation of R.N. AZEVEDO, entitled "Da punição corporal ao abuso físico de crianças/adolescentes: caracterização, níveis de gravidade e variáveis psicossociais associadas". Universidade de São Paulo, 2017.

How to cite this article

Azevedo, R. N., \& Bazon, M. R. (2021). Severity levels of physical punishment of children/adolescents: cluster analysis. Estudos de Psicologia (Campinas), 38, e190088. https://doi.org/10.1590/1982-0275202138e190088
} 
níveis de gravidade associados a diferenças em variáveis psicossociais apontadas como fatores de risco para os abusos fisicos. Adotou-se uma abordagem quantitativa, com delineamento transversal e método de clusterização. Participaram 87 pais/cuidadores adeptos a práticas de punição física. As análises indicaram a existência de três agrupamentos que se diferenciaram no tocante à gravidade da punição corporal e em algumas das variáveis psicossociais, denotando a importância de os serviços/programas voltados ao enfrentamento da violência contra as crianças/adolescentes considerarem estratégias de intervenção psicossocial distintas e específicas a cada grupo.

Palavras-chave: Maus-tratos infantis; Relações familiares; Punição; Serviços sociais.

The high prevalence of child abuse and the severity of its consequences justify any and all investment in primary and secondary prevention (Lopes, Górni, Mattar, \& Williams, 2018; Ridings, Beasley, \& Silovsky, 2017; Ward, Sanders, Gardner, Mikton, \& Dawes, 2016). Particularly regarding physical abuse, there has been progress in child protection mechanisms in several countries around the world. In the wake of the Convention on the Rights of the Child, promulgated in 1989, the signatory countries were called upon to state the prohibition of physical punishment in law, which, according to Ribeiro (2016), has been happening gradually, although with resistance and slowness.

In Brazil, although the Federal Constitution and the Estatuto da Criança e do Adolescente (Child and Adolescent Statute) have established new parameters to deal with children and adolescents, physical punishments (corporal punishment) have not been clearly addressed, leaving room for different opinions and disagreement on the subject. The so-called Lei Menino Bernardo (Boy Bernardo's Law) (Law n 13.010/2014), also known as the spanking law, would have been edited to clarify issues in this area. For the purposes of this study, we will address the Art. $1^{\text {st }}$ in this Law. It stipulates that children and adolescents have the right to be educated and cared for without the use of physical punishment or cruel or degrading treatment with the purpose of correcting, disciplining, educating or under any other pretext, and it defines physical punishment: "action of a disciplinary or punitive nature applied with the use of physical force on the child or adolescent that results in physical suffering or injury" and cruel or degrading treatment: "conduct or cruel form of treatment against the child or adolescent that humiliates, seriously threatens or ridicules them" (Presidência da República, 2014, Art. 1, our translation)2.

Boy Bernardo's Law did not actually prohibit physical punishment, but only those that result in 'physical suffering' or 'injuries'. Taking into account the objective nature of what is considered 'injury', the big question is the wide scope for what will can be considered 'physical suffering', since there is no objective criteria for identifying/measuring it (Pereira, 2014). Despite this gap, the law introduces social control measures such as family protection programs and courses in counseling, psychological or psychiatric treatment for parents/ caregivers, in addition to issuing warnings to the offender. In more serious cases, the parent/caregiver might lose custody, guardianship or their legal authority may be revoked. Thus, it recognizes the importance of developing and offering psychosocial interventions to parents/caregivers as a policy aligned with the strategies recommended by the World Health Organization (2016).

This perspective imposes the need to understand the specific needs of families. Research points to the existence of different levels of severity of physical abuse, underlining the importance of devising responses adjusted to different standards (Larrivée, Tourigny, \& Bouchard, 2007). As there are severity distinctions, there are certainly variations in the exposure of families to different psychosocial risk factors (either in intensity or in variety). In accordance with this reasoning, the general objective of the study was to verify whether, in a

$\checkmark v \nabla$

2 In original: Castigo físico: "ação de natureza disciplinar ou punitiva aplicada com o uso da força física sobre a criança ou o adolescente que resulte em sofrimento físico; ou lesão" e tratamento cruel ou degradante: "conduta ou forma cruel de tratamento em relação à criança ou ao adolescente que humilhe, ameace gravemente, ou ridicularize" (Presidência da República, 2014, Art. 1). 
sample of parents/caregivers who practice physical/corporal punishment, there would be different subgroups regarding the psychosocial variables pointed out in the literature as risk factors for physical abuse, taking into account the differences in the pattern of conduct of physically punishing the child/adolescent, in terms of modalities of punishment, frequency of punishment, regions of the child's body affected and the presence of irritation/anger when punishing.

It is believed that the identification of subgroups would offer clues about the phenomenon itself, the different expressions, and etiologies, as well as guidelines for necessary programs/services. Different patterns of physical/corporal punishment were assumed, from the least severe to the most severe (in terms of the potential for physical harm to the child/adolescent), requiring different levels of intervention (in terms of intensity and modality), although they should all be equally reprehended, as physical harm is a violation of the child's rights and it represents a risk to their psychosocial development.

\section{Method}

\section{Participants}

A sample of 87 parents/caregivers from a small city (approximately 40 thousand inhabitants) near the city of Ribeirão Preto, São Paulo, participated in the survey. In order to ensure the participation of parents/caregivers with different levels of the problem, participants were recruited in two different contexts: 40 participants from the Centro de Referência Especializado de Assistência Social (Specialized Reference Center for Social Assistance) in the municipality (with a history of notification to the child protection system); 47 participants from the community recruited at afterschool programs (with no history of notification to the protection system). It is important to mention that, in principle, 60 participants were recruited from community programs. However, 13 (thirteen) participants said they did not use any form of physical punishment with their children. Thus, their data were excluded from the analyses.

\section{Instruments}

The following instruments were used to collect the data.

Sociodemographic Characterization Questionnaire - It was developed by Bringiotti (1999): It collects information that enables the sociodemographic characterization of the parents/caregivers responsible for children. It included issues inherent to the 2014 Brazil Criterion (year in which the data were collected) for socioeconomic classification (Associação Brasileira de Empresas de Pesquisa, 2014).

Semi-structured Interview Guide on Parental Practice: It consists of 29 questions that were designed to research and collect information on parental practice, with special attention to physical/corporal punishment, to characterizing them in terms of modality (way of acting), frequency, reasons for physical punishment, situations and emotional conditions when applying the punishment.

Child Abuse Potential Inventory (CAP) - It was developed by Milner (1986): To measure parents'/ caregivers' risk for abuse, based on the measurement of certain psychosocial characteristics. The CAP has been translated and adapted in several countries; in Brazil it was translated and semantically adapted by Ávila de Mello et al. (2008) for research. Bergamo, Pasian, Ávila de Mello, and Bazon (2009) and Rios, Williams, Schelini, Bazon, and Piñon (2013) investigated and obtained evidence of good reliability and validity. It consists of 160 statements and participants indicate the extent of their agreement by choosing "I agree" or "I disagree". The items form the factors/scales. The main one is abuse, which is related to six subdimensions: 
distress, rigidity, unhappiness, problems with the child and with oneself, problems with the family, problems with others. The higher the value on the abuse scale, the greater the potential for abuse. The two other scales are ego strength and loneliness. As the scores for each item are not fixed, the maximum abuse score is 486. In the North American reality, scores equal to or greater than 215 points indicate a significant risk for child abuse.

Family Adaptability and Cohesion Evaluation Scales - IV (FACES-IV): It is the most recent version of the instrument developed to assess family's functioning (Olson, 2000), taking into account three components that structure family relationships: cohesion (degree of closer family ties), flexibility (family's ability to make changes in leadership, roles and rules) and communication (facilitating dimension of movement in other dimensions). It consists of 62 items that consist of a series of statements answered on a five-point Likert Scale. The items comprise the scales that can be "balanced" (cohesion and flexibility) or "unbalanced" (the extremes of cohesion - enmeshed families and disengaged families -, and the extremes of flexibility - rigid families and chaotic families), in addition to the scales on communication and family satisfaction. In the balanced scales, communication and satisfaction, the higher the score, the better the family's functioning in that dimension. In the unbalanced scales, the higher the score, the worse the family's functioning. In Brazil, the Portuguese version was organized by Santos et al. (2013), which was tested in an empirical study and its applicability was verified (Santos, Bazon, \& Carvalho, 2017).

Social Support Questionnaire (SSQ) - Originally proposed by Sherbourne and Stewart (1991): This instrument assesses the degree to which facets of social support (emotional, material, affective, informational, and positive social interaction) are perceived as satisfactory by the individual. The respondents indicate if they can 'count on someone' when facing a specific situation, on a five-point Likert Scale: never, rarely, sometimes, almost always, always. Another construct, the social network, refers to the network of relationships that surround the individual and their characteristics. In this regard, respondents must report the number of people they trust and whether they participate in community activities. It was translated and validated for the Brazilian context by Chor, Griep, Lopes, and Faertein (2001) and by Griep, Chor, Faerstein, and Lopes (2003).

\section{Procedures}

Data were collected throughout 2014. Collections were carried out at the participants' homes after they signed a free and informed consent form. Only the parents/caregivers of the children were approached, and they responded the instruments orally, thus granting an interview. The project had been previously analyzed and approved by the Research Ethics Committee with human beings of the Faculdade de Filosofia, Ciências e Letras de Ribeirão Preto (School of Philosophy, Sciences and Art of Ribeirão Preto), University of São Paulo (CAAE approval protocol n 368416614.8.0000.5407). The data collected with the standardized instruments were corrected according to the technical standards of each one, and the scores were compiled. The data collected using the Sociodemographic Characterization Questionnaire and the Semi-structured interview on parental practice were analyzed using content analysis, so that they could be synthesized and, thus, quantified, to be compiled. It should be emphasized that the analysis of parenting practices aimed, at first, to identify those mentioned spontaneously, and then to deduce categories of the modalities of physical/ corporal punishment. Then, they were organized in ascending order of potential damage/physical harm, thus assigning them a representative score in that order. The order was based on the literature (Fréchette, Zoratti, \& Romano, 2015; Wong, Chen, Goggins, Tang, \& Leung, 2009) and two consulted pediatric professionals. Table 1 shows the categories that summarize the practices of physical punishment, rank ordered according

4 to the potential for harm/injury. 
Table 1

The modalities of punishment and the scores on the Severity Scale (from the least damaging to the potentially most damaging)

\begin{tabular}{lc}
\hline Modality of punishment & Scores \\
\hline Kneeling & 1 \\
Pulling hair & 1 \\
Pulling the ear & 1 \\
Pinching & 1 \\
Tying up & 2 \\
Spanking & 2 \\
Slapping & 3 \\
Giving "croques" (hitting the head with knuckles) & 4 \\
Shaking & 5 \\
Pushing & 5 \\
Throwing objects & 6 \\
Lashing & 7 \\
Punching & 7 \\
Beating & 7 \\
Strangling & 8 \\
Banging the head against the wall & 8 \\
\end{tabular}

The data on parenting practices were analyzed to identify and categorize the information concerning the frequency of punishment and the main regions of the child's body affected by punishment. Frequency is an important element because if physical punishment is frequent, even if not severe, the risk of physical and psychological suffering increases (Taillieu, Afifi, Mota, Keyes, \& Sareen, 2015). The frequency data was classified into pre-established categories: daily; two or three times a week; once a week; once a month; less than once a month. With regard to the child's body region, the following body regions were ordered in terms of the risk potential for health problems (from the lowest to the highest risk potential), according to the literature and the consulted pediatric professionals: regions below the waist, score 1; hands and arms, score 2; torso (including back and thorax), score 3; head and face, score 4.

The information collected about the "feeling during the act of punishing" was presented according to the presence/absence of the irritation/anger category, scoring if present. The feeling of irritation/anger during the act of physical/corporal punishment characterizes the action as a discharge of negative emotions, which also increases the risk of physical harm/injury and/or psychological harm to the child/adolescent, depriving the practice of any educational value (Martín, 2003).

Thus, the possibility of assessing the levels of severity of physical/corporal punishment practices was established by combining the four variables (1) modality; (2) frequency; (3) body region; and (4) emotional state (presence or absence of anger) and using a clustering procedure (clusters) by applying the K-means method. The Hopkins method has been previously used to identify if the data had a 'tendency to cluster'. The result was $H=0.25$, which was adequate (ranging from 0 to 1 - the more distant from 0.5 , the more adequate for the clustering procedure). The ideal number of clusters was calculated using the NbClust package (Charrad, Gazzali, Boiteau, \& Niknafs, 2014). The formed clusters were described and then compared in relation to the variables evaluated by CAP, FACES-IV and SSQ using the Kruskal-Wallis non-parametric test. The Chi-square test was used to compare the clusters in relation to the categorical variables.

\section{Results}

The analyses formed three different clusters in terms of the severity of physical/corporal punishment. Table 2 shows the clusters according to the different modalities of punishment, frequency of punishment, regions of the child's body affected and the presence of irritation/anger when punishing, and their sociodemographic characterization. 
Table 2

Clusters identified, according to cluster analyses, socio-demographically characterized and compared in variables (standardized), parameters of severity of corporal punishment

\begin{tabular}{|c|c|c|c|c|c|c|c|c|c|c|c|}
\hline \multirow[b]{2}{*}{ Variables } & \multicolumn{3}{|c|}{ Cluster $1(n=12)$} & \multicolumn{3}{|c|}{ Cluster $2(n=44)$} & \multicolumn{3}{|c|}{ Cluster $3(n=31)$} & \multirow[b]{2}{*}{$\mathrm{H}$} & \multirow[b]{2}{*}{$p$} \\
\hline & M & $D P$ & $\begin{array}{c}\text { Mean } \\
\text { Rank }\end{array}$ & M & $D P$ & $\begin{array}{l}\text { Mean } \\
\text { Rank }\end{array}$ & M & $D P$ & $\begin{array}{l}\text { Mean } \\
\text { Rank }\end{array}$ & & \\
\hline Age & 31.6 & 9.6 & 33.7 & 38.8 & 12.2 & 49.0 & 33.7 & 8.5 & 40.9 & 4.22 & 0.12 \\
\hline Age $1^{\text {st }}$ child & 19.9 & 3.7 & 44.0 & 20.7 & 6.3 & 43.4 & 20.3 & 4.7 & 43.5 & 0.02 & 1.00 \\
\hline No of children & 2.7 & 1.0 & 43.6 & 3.2 & 3.0 & 42.4 & 3.3 & 3.3 & 45.0 & 0.20 & 0.91 \\
\hline Years of schooling & 7.4 & 2.9 & 49.6 & 6.6 & 3.7 & 43.3 & 6.4 & 2.5 & 42.9 & 0.69 & 0.71 \\
\hline Modality of punishment & $-0.5^{\mathrm{a}}$ & 0.7 & 29.5 & $-0.5^{\mathrm{a}}$ & 0.6 & 31.9 & $0.9^{\mathbf{b}}$ & 0.9 & 66.7 & 39.3 & $0.00^{* *}$ \\
\hline Body regions & $-0.3^{\mathrm{a}}$ & 0.7 & 37.3 & $-0.4^{\mathrm{a}}$ & 0.6 & 34.6 & $0.7^{\mathbf{b}}$ & 1.1 & 59.9 & 19.7 & $0.00^{* *}$ \\
\hline Frequency of punishment & $-0.2^{\mathbf{b}}$ & 1.0 & 38.1 & $-0.7^{\mathrm{a}}$ & 0.5 & 28.2 & $1.0^{c}$ & 0.6 & 68.7 & 53.0 & $0.00^{* *}$ \\
\hline Feeling anger & $-2.3^{\mathrm{a}}$ & 0.0 & 7.5 & $0.4^{b}$ & 0.0 & 51.0 & $0.3^{\mathbf{b}}$ & 0.7 & 48.2 & 72.3 & $0.00^{* *}$ \\
\hline
\end{tabular}

Note: ** Statistically significant at the level of 0.01 . In the lines, the means with the same letters are not different among them by the Tukey post-test $(p<0.05)$, in which: $\mathrm{a}<\mathrm{b}<\mathrm{c}$.

M: Mean; SD: Standard Deviation.

It was observed, regarding the modalities of physical punishment and the child's body regions affected by punishment, that clusters 1 and 2 did not differ from each other but differed from cluster 3. In cluster 3 , participants would use modalities with greater potential for harm/injury in more vulnerable body regions, when compared to clusters 1 and 2. Regarding the frequency of physical punishment, the three clusters differed, with an increase in the use of physical punishment from cluster 2 to 1 and from 1 to 3 . As for the feeling of irritation/anger, the participants in cluster 1 presented these feelings less frequently, when compared with participants in clusters 2 and 3. Clusters 1 and 2 were primarily composed of participants with no history of notification to the protection system $(66.60 \%$ and $75.00 \%$, respectively), while cluster 3 was primarily composed of participants with a history of notification $(80.35 \%$ of the total).

The clusters were not significantly different in the following sociodemographic characterization variables: age of participants; ages at which they had their first child; number of children; years of schooling. They also did not show any significant differences regarding marital status $\left(\chi^{2}=3.0\right.$ and $\left.p=0.22\right)$, as the majority stated they were married or in a stable relationship $(33.00 \%$ in cluster $1 ; 36.00 \%$ in cluster $2 ; 3.35 \%$ in cluster 3). A difference regarding the economic class, according to the Critério Brasil (Associação Brasileira de Empresas de Pesquisa, 2014) was observed. Although most participants in all clusters were classified in the C2 and DE strata $\left(\chi^{2}=7.4\right.$ and $\left.p=0.29\right)$, significantly more participants in cluster 3 were classified in the DE strata (considering the adjusted standardized residual $=2.2$ ): $33.00 \%$ in cluster $1 ; 45.00 \%$ in cluster $2 ; 68.00 \%$ in cluster 3). Significant differences between the clusters were also observed in the psychosocial variables (Table 3, 4 and 5).

Table 3

Statistical comparison of clusters in terms of mean and standard deviation in the factors of the Child Abuse Potential Inventory

\begin{tabular}{|c|c|c|c|c|c|c|c|c|c|c|c|}
\hline \multirow[b]{2}{*}{ Scales and subscales } & \multicolumn{3}{|c|}{ Cluster $1(n=12)$} & \multicolumn{3}{|c|}{ Cluster $2(n=44)$} & \multicolumn{3}{|c|}{ Cluster $3(n=31)$} & \multirow[b]{2}{*}{$\mathrm{H}$} & \multirow[b]{2}{*}{$p$} \\
\hline & M & $D P$ & $\begin{array}{c}\text { Mean } \\
\text { Rank }\end{array}$ & M & $D P$ & $\begin{array}{c}\text { Mean } \\
\text { Rank }\end{array}$ & M & $D P$ & $\begin{array}{c}\text { Mean } \\
\text { Rank }\end{array}$ & & \\
\hline Abuse & $202.0^{a}$ & 106.7 & 34.4 & $226.2^{a}$ & 106.0 & 39.9 & $281.7^{\mathbf{b}}$ & 95.2 & 53.5 & 7.25 & $0.03^{*}$ \\
\hline Distress & 107.8 & 67.8 & 34.5 & 127.9 & 72.6 & 40.7 & 162.6 & 71.7 & 52.4 & 5.89 & 0.05 \\
\hline Rigidity & $33.1^{\mathrm{a}}$ & 17.5 & 36.5 & $4.2^{\mathrm{a}}$ & 14.0 & 36.8 & $45.6^{\mathbf{b}}$ & 13.8 & 57.1 & 13.06 & $0.00^{* *}$ \\
\hline Unhappiness & 27.0 & 21.3 & 41.1 & 26.1 & 16.6 & 41.3 & 30.1 & 15.0 & 48.9 & 1.83 & 0.40 \\
\hline Problems oneself / child & 4.0 & 6.5 & 36.0 & 5.3 & 6.5 & 44.4 & 5.4 & 6.1 & 46.6 & 1.61 & 0.45 \\
\hline Family problems & 14.7 & 16.2 & 38.9 & 17.4 & 13.9 & 43.8 & 19.3 & 14.0 & 46.2 & 0.74 & 0.69 \\
\hline Problems with others & 15.5 & 7.8 & 41.2 & 14.7 & 7.7 & 38.9 & 18.7 & 7.0 & 52.4 & 5.54 & 0.06 \\
\hline Ego strength & $21.6^{\mathbf{b}}$ & 8.8 & 53.7 & $19.3^{\mathbf{b}}$ & 10.2 & 48.5 & $13.6^{\mathrm{a}}$ & 9.6 & 33.8 & 8.20 & $0.02^{*}$ \\
\hline Loneliness & 8.2 & 4.5 & 38.3 & 8.5 & 4.4 & 40.1 & 10.5 & 4.3 & 51.8 & 4.67 & 0.10 \\
\hline
\end{tabular}

Note: *Statistically significant at the level of $0.05 ;{ }^{* *}$ Statistically significant at the level of 0.01 . In the lines, the means with the same letters were not different among them by the Tukey post-test $(p<0.05)$, in which: $a<b<c$. 
Table 4

Statistical comparison of clusters in terms of mean and standard deviation on the Family Adaptability and Cohesion Evaluation Scales - IV

\begin{tabular}{|c|c|c|c|c|c|c|c|c|c|c|c|}
\hline \multirow[b]{2}{*}{ Scales } & \multicolumn{3}{|c|}{ Cluster $1(n=12)$} & \multicolumn{3}{|c|}{ Cluster $2(n=44)$} & \multicolumn{3}{|c|}{ Cluster $3(n=31)$} & \multirow[b]{2}{*}{$\mathrm{H}$} & \multirow[b]{2}{*}{$p$} \\
\hline & $M$ & $D P$ & $\begin{array}{c}\text { Mean } \\
\text { Rank }\end{array}$ & M & $D P$ & $\begin{array}{c}\text { Mean } \\
\text { Rank }\end{array}$ & M & $D P$ & $\begin{array}{c}\text { Mean } \\
\text { Rank }\end{array}$ & & \\
\hline Cohesion & $27.4^{\mathbf{b}}$ & 6.5 & 54.0 & $26.8 \mathrm{~b}$ & 5.3 & 47.7 & $23.2^{\mathrm{a}}$ & 7.3 & 34.9 & 6.95 & $0.03^{*}$ \\
\hline Flexibility & 23.1 & 5.3 & 47.8 & 23.4 & 5.1 & 48.9 & 20.3 & 5.8 & 35.5 & 5.44 & 0.07 \\
\hline Disengaged & 17.0 & 6.6 & 37.9 & 17.2 & 6.0 & 39.9 & 19.8 & 6.5 & 52.1 & 5.10 & 0.08 \\
\hline Enmeshed & 20.1 & 4.9 & 49.7 & 19.3 & 5.0 & 45.6 & 18.1 & 5.1 & 39.5 & 1.79 & 0.41 \\
\hline Rigid & 17.9 & 5.7 & 36.8 & 18.5 & 3.5 & 43.9 & 19.3 & 4.3 & 47.0 & 1.42 & 0.49 \\
\hline Chaotic & 15.9 & 5.6 & 36.7 & 17.9 & 5.3 & 43.3 & 19.1 & 6.2 & 47.8 & 1.75 & 0.42 \\
\hline Communication & 34.3 & 10.3 & 50.6 & 33.3 & 8.1 & 48.3 & 29.2 & 7.4 & 35.3 & 5.82 & 0.05 \\
\hline Satisfaction & $29.4^{\mathrm{b}}$ & 9.1 & 46.6 & $28.9 \mathrm{~b}$ & 7.4 & 50.0 & $24.5^{a}$ & 7.3 & 34.4 & 7.14 & $0.03^{*}$ \\
\hline
\end{tabular}

Note: *Statistically significant at the level of 0.05 . In the lines, the means with the same letters were not different among them by the Tukey post-test $(p<0.05)$, in which: $a<b<c$.

M: Mean; SD: Standard Deviation.

Table 5

Statistical comparison of clusters in terms of mean and standard deviation on the Social Support Questionnaire

\begin{tabular}{|c|c|c|c|c|c|c|c|c|c|c|c|}
\hline \multirow[b]{2}{*}{ Network and Social Support } & \multicolumn{3}{|c|}{ Cluster $1(n=12)$} & \multicolumn{3}{|c|}{ Cluster $2(n=44)$} & \multicolumn{3}{|c|}{ Cluster $3(n=31)$} & \multirow[b]{2}{*}{$\mathrm{H}$} & \multirow[b]{2}{*}{$p$} \\
\hline & M & $D P$ & $\begin{array}{c}\text { Mean } \\
\text { Rank }\end{array}$ & M & $D P$ & $\begin{array}{l}\text { Mean } \\
\text { Rank }\end{array}$ & M & $D P$ & $\begin{array}{c}\text { Mean } \\
\text { Rank }\end{array}$ & & \\
\hline \multicolumn{12}{|l|}{ Network } \\
\hline Parents & 1.4 & 1.7 & 44.0 & 1.6 & 1.8 & 46.9 & 1.0 & 0.9 & 39.9 & 1.50 & 0.47 \\
\hline Friends & 1.6 & 1.7 & 47.3 & 1.4 & 1.5 & 45.6 & 1.1 & 1.2 & 40.5 & 1.08 & 0.58 \\
\hline \multicolumn{12}{|l|}{ Activities } \\
\hline Sports & 0.1 & 0.3 & 44.6 & 0.0 & 0.2 & 43.0 & 0.1 & 0.3 & 45.2 & 0.78 & 0.68 \\
\hline Association & 0.0 & 0.0 & 43.5 & 0.0 & 0.2 & 44.5 & 0.0 & 0.0 & 43.5 & 0.98 & 0.61 \\
\hline Voluntary & $0.1^{b}$ & 0.3 & 47.1 & $0.0^{\mathrm{a}}$ & 0.0 & 43.5 & $0.0^{\mathrm{a}}$ & 0.0 & 43.5 & 6.25 & $0.04^{*}$ \\
\hline \multicolumn{12}{|l|}{ Social Support } \\
\hline Material & $17.7^{b}$ & 3.3 & 54.3 & $16.5^{\mathbf{b}}$ & 3.9 & 47.7 & $14.2^{\mathrm{a}}$ & 4,9 & 34.8 & 7.47 & $0.02^{*}$ \\
\hline Emotional & 10.3 & 3.7 & 40.8 & 11.4 & 3.7 & 46.7 & 10.7 & 4.3 & 41.4 & 1.02 & 0.60 \\
\hline Informational & 11.3 & 3.6 & 39.7 & 12.1 & 3.2 & 47.0 & 11.5 & 3.7 & 41.4 & 1.35 & 0.51 \\
\hline Affective & 10.9 & 4.2 & 49.4 & 11.0 & 3.2 & 47.4 & 9.8 & 3.0 & 37.1 & 3.75 & 0.15 \\
\hline Social I. Positive & 10.7 & 4.6 & 42.7 & 12.0 & 4.5 & 47.6 & 10.4 & 4.0 & 39.4 & 2.00 & 0.37 \\
\hline Total Score & 60.9 & 14.6 & 44.3 & 63.3 & 14.5 & 48.4 & 56.5 & 16.8 & 37.7 & 3.24 & 0.20 \\
\hline
\end{tabular}

Note: *Statistically significant at the level of 0.05 . In the lines, the means with the same letters were not different among them by the Tukey post-test $(p<0.05)$. in which: $a<b<c$.

M: Mean; SD: Standard Deviation.

\section{Discussion}

The severity, in terms of modalities of punishment, frequency of punishment, regions of the child's body affected by punishment and feelings of anger, and some psychosocial characteristics, of parents/caregivers who adhere to the investigated physical punishment practices were found to be different. Three clusters stood out: 1, 2 and 3, in order of severity, in which 1 and 2 were primarily composed of participants recruited from the community, with no history of notification to the child protection system, and 3, mostly composed of participants with a history of notification. The latter cluster was composed of parents/caregivers who would resort to practices characterized by more severe and frequent modalities of punishment, which would focus on the most vulnerable regions of the child's body and were most likely moved by irritation/anger. In comparison, clusters 1 and 2 were composted of parents/caregivers who practiced less severe punishments. These two clusters, in fact, are similar to each other, differing only in the frequency of physical punishment (cluster 1 presenting the highest average) and presence of irritation/anger when punishing (cluster 2 showing a higher number of participants with this characteristic, resembling cluster 3 in this aspect).

Despite the differences in the patterns of physical/corporal punishment, the sociodemographic characteristics of the participants in the three clusters were not different. The investigated sample was 
homogeneous in terms of the participants' age, age at which they would have their first child, number of children under their care, education, and marital status. Regarding the economic class, however, although most participants in the clusters were classified in C2 and DE strata, there were more participants in the DE stratum in cluster 3, representing an economically less favored strata, which denotes greater social vulnerability. Socioeconomic disadvantage constitutes a source of family stress, making parents/caregivers, in this context, more susceptible to the negative effects of risk factors specific to child abuse (Larriveé et al., 2007, St-Germain, Baudry, \& Bussières, 2016; Ward et al., 2016; Wong et al., 2009).

Psychosocial differences that require attention when proposing services/programs in the area were also identified. In terms of the psychological functioning of caregivers, the assessment carried out using the CAP pointed out that clusters 1 and 2 would be similar, and that both would be distinct from cluster 3 in the abuse (and rigidity subdimension) and ego strength scales. It follows that participants in cluster 3 would feel more fragile and emotionally unstable and experience more negative feelings, characterized by feelings of anxiety, sadness, irritability and low self-esteem, corroborating studies in the area (Bérgamo \& Bazon, 2012; Rodriguez, Russa, \& Kircher, 2015). The mean scores on the abuse scale were 202 points, 226 points and 281 points, respectively. Considering the American cut-off score (215 points), in an exploratory way, the mean score in the three clusters can be considered high, although it was only higher than 215 in clusters 2 and 3, yet cluster 2 was not statistically different from cluster 1. In a recent study conducted with parents/caregivers whose custody of their children was revoked by the Brazilian and Peruvian Court of Justice, where CAP was also used, the mean score in the Brazilian sample $(n=30)$ on the abuse scale was 252.5, higher than the American cut-off score, however, lower than the one obtained in cluster 3 (Carpio, 2016). In another study with Brazilian parents/caregivers conducted to comparatively assess a sample notified for physical abuse $(n=30)$ and a control group $(n=30)$, a significant difference was found between the groups. The difference between notified parents/caregivers who obtained a mean score of 223.87 on the abuse scale, also higher than the American cut-off score, however, was slightly lower than the one obtained in cluster 2, and much lower than the one in cluster 3 (Bérgamo \& Bazon, 2012). The combined data suggest that cluster 3 would indicate that parents/caregivers clearly require psychological attention due to negative feelings and a tendency to interpret, in a more generalized and more stable way, child behavior as negative, tending to attribute the child's behavior as hostile (as can be seen in the rigidity subdimension) (Milner, 1986). Furthermore, considering the results on the ego strength scale, the parents/caregivers in this group would feel less adequate on the interpersonal level and less emotionally stable (that is, less emotional self-control). These aspects are important in the etiology of intrafamily violence (Milner, 1986). Cluster 2 would, in turn, represent parents/caregivers who were vulnerable on a psychological level, in terms of negative feelings, which is consistent with the fact that they were similar to cluster 3 regarding irritation/anger when punishing (distinguishing itself from cluster 1 , at that point).

Regarding family's functioning, considering the results of FACES-IV, clusters 1 and 2 presented no significant differences. These were observed only when comparing cluster 3 with clusters 1 and 2 on the cohesion and satisfaction scales. In both scales, the mean values were lower in cluster 3 , indicating that the participants in this group would perceive family ties as more fragile, showing less reciprocal concern of members and less satisfaction with family life. Carpio (2016) also used FACES-IV in his research in the Brazilian sample who had their custody revoked and found the mean values $M=24.94$ for cohesion and $M=27.20$ for satisfaction. Comparing the results, the clinical group of Carpio (2016) obtained a higher mean value than the one in cluster 3, which shows more preserved family functioning in terms of cohesion and family satisfaction. These data reveal that participants in cluster 3 would represent parents/caregivers who experience more problems in the context of the family microsystem regarding family ties.

As for family relationships with the surroundings and their social belonging network, assessed by the 8 SSQ, cluster 1 was different from the others in the sense that the parents/caregivers in this group voluntarily 
engage more and with more frequently in community activities. Participation in community activities favors closer ties among the members of the community, which can be an important source of social support. The feeling of belonging to the community, the exchange of information and experiences and the support that the members of the community can offer each other are elements of protection of great relevance (Ridings et al., 2017). Actions aimed to promote these elements have recently been incorporated into Brazilian public policies on social assistance (Conselho Nacional de Assistência Social, 2009).

As for perceived "social support", there was a significant difference between the groups in the material support dimension, which occurred between groups 1 and 2 and group 3, that is, the participants in this group believe they receive less material support. Considering that a greater number of families in this group come from an economically lower strata, probably more socially vulnerable, support concerning real daily issues can assume special importance, particularly due to the stress that living conditions can create in the family. Material or instrumental support refers to the experience of receiving help, for example, to prepare food on a day when you are sick and unable to do so, or help from someone to "look after the children" while one goes to the bank to resolve pending issues.

Carpio (2016) also used the SSQ to assess the participants in his investigation. In the Brazilian sample, the mean values obtained in the study were similar to those of the present study with regard to the size of the network of relatives $(M=1.03)$ and friends $(M=1.67)$. The mean values for social support were also similar in most dimensions (material support $M=12.97$, emotional support $M=12.87$, informational support $M=12.40$, affective support $M=10.33$ and positive social interaction $M=10.4$ ). It is noteworthy that emotional support and informational support are lower in the three groups of the present study when compared to the data found by Carpio (2016). As for material support, the participants in his study presented lower scores, indicative of poorer support in terms of real daily issues.

In sum, when considering services/programs, in view of the levels of severity that physical punishment can assume, according to the groups identified in the present study, there are parents/caregivers who seem to require only educational actions aiming to discourage the use of physical punishment and expand their repertoire of parental skills, teaching them alternatives to physical punishment (cluster 1). Secondly, there are the emotionally vulnerable parents/caregivers who seem to require support for the development of their emotional regulation capacities, or more specifically, anger control, to reduce the chances of physical punishment as a consequence of this feeling (cluster 2). Finally, there are socially and psychologically vulnerable parents/caregivers who experience a less supportive family and community environment. For these, combined with actions related to assistance policies aiming to improve their socioeconomic conditions, the general objective of programs/services must be to improve their psychological functioning, as well as that of their family, in terms of strengthening the bond among their members and with the community. Programs/services tailored to assist these parents in this third group require more complex actions and specialized human resources.

There are certainly methodological limitations of the study. One is related to the conduct of physical punishment measured using self-report data. In addition to the difference between "what is done" and "what is said to be done", answers could have been probably biased by social desirability. As the data was related to spontaneously reported forms of physical punishment, which perhaps does not include other less usual punishments, for example, "depriving the child of food", the possibility of underestimating the data regarding the modalities and frequency of reported physical punishment must be considered. In the same direction, the severity of physical punishment was assessed by means of some variables, despite other equally relevant ones, such as, for example, threats to psychological integrity (and not only physical). Despite these limitations that can be overcome in further studies, the results obtained showed that parents/caregivers who practice physical punishment do not do it in the same way and are not exposed to the same risk factors, which represent different difficulties/needs that require reflection on the importance of developing programs/ services to meet the different demands. 


\section{Contributors}

R. N. AZEVEDO performed data analysis and the writing of the manuscript. M. R. BAZON revised the manuscript. Both authors were responsible for designing the study and discussing the results.

\section{References}

Associação Brasileira de Empresas de Pesquisa. (2014). Critério de classificação econômica Brasil: 2014. São Paulo: Autor. Recuperado de http://www.abep.org/criterio-brasil

Ávila de Mello, I. L. M., Bérgamo, L. P. D., Piñon, E. A., Rios, K. S. A., Williams, L. C. A., \& Bazon, M. R. (2008). Inventário de Potencial de Abuso Infantil - CAP: versão brasileira. São Carlos: LAPREV.

Bérgamo, L. P. D., \& Bazon, M. R. (2012) Abuso infantil: avaliando fatores de risco psicológicos em cuidadores notificados. Psicologia: Reflexão e Crítica, 25(2), 256-264. https://doi.org/10.1590/S0102-79722012000200007

Bérgamo, L. P. D., Pasian, S. R., Mello, I. L. M. A., \& Bazon, M. R. (2009). O inventário de potencial de maus-tratos infantil: estudo de precisão e validade. Avaliação Psicológica, 8(3), 425-435. Recuperado de http://pepsic.bvsalud. org/pdf/avp/v8n3/v8n3a14.pdf

Bringiotti, M. I. (1999). Maltrato infantil: factores de riesgo para el maltrato físico en la poblacion infantil que concurre a las escuelas dependientes del gobierno de la ciudad de Buenos Aires. Madrid: Niño y Dávila Editores.

Carpio, R. T. (2016) Estudo comparativo de famílias com a guarda dos filhos suspensa por medida de proteção, no Brasil e no Peru (Dissertação de mestrado não-publicada). Universidade de São Paulo. https://doi.org/10.11606/D.59.2017. tde-09012017-011833

Charrad, M., Ghazzali, N., Boiteau, V., \& Niknafs, A. (2014). NbClust: an R package for determining the relevant number of Clusters in a data set. Journal of Statistical Software, 61(6), 1-36. Retrieved from http://www.jstatsoft.org/v61/i06/

Chor, D., Griep, R. H., Lopes, C. S., \& Faertein, E. (2001) Medidas de rede e apoio social no Estudo Pró-Saúde: pré-testes e estudo piloto. Cadernos de Saúde Pública, 17(4), 887-896. Recuperado de http://www.scielo.br/pdf/\%0D/csp/ v21n3/04.pdf

Conselho Nacional de Assistência Social. (2009). Resolução n 109, de 11 de novembro de 2009. Aprova a Tipificação Nacional de Serviços Socioassistenciais. Diário Oficial da União. Brasília: Autor. Recuperado de http://www.mds.gov. br/webarquivos/public/resolucao_CNAS_N109_\%202009.pdf

Fréchette, S., Zoratti, M., \& Romano, E. (2015) What is the link between corporal punishment and physical abuse? Journal of Family Violence, 30, 135-148. https://doi.org/10.1007/s10896-014-9663-9

Griep, R. H., Chor, D., Faerstein, E., \& Lopes, C. (2003). Apoio social: confiabilidade teste-reteste da Escala no Estudo Pró-Saúde. Cadernos de Saúde Pública, 19(2), 625-634. https://doi.org/10.1590/S0102-311X2003000200029

Larrivée, M. C., Tourigny, M., \& Bouchard, C. (2007). Child physical abuse with and without other forms of maltreatment: dysfunctionality versus dysnormality. Child Maltreatment, 12(4), 303-313. https://doi.org/10.1177/1077559507305832

Lopes, N. R. L., Górni, S. M., Mattar, V. O., \& Williams, L. C. A. (2018) Assessment of a brief intervention with parents to prevent shaken baby syndrome. Paidéia, 28, 1-9, e2823. https://doi.org/10.1590/1982-4327e2823

Martín, M. M. B. (2003). Las acciones punitivas físicas: una perspectiva intercultural. Estudios Pedagógicos, 29, 85-95. https://doi.org/10.4067/S0718-07052003000100006

Milner, J. S. (1986) The child abuse potential inventory: manual. Webster: Psytec.

Olson, D. H. (2000). Circumplex model of marital and family systems. Journal of Family Therapy, 22(2), 144 167. https:// doi.org/10.1111/1467 6427.00144

Pereira, P. H. S. (2014). Observações prefaciais à Lei 13.010/2014, Lei Menino Bernardo. Revista Jus Navigandi, 19,(4030), 1-15. Recuperado de https:/jus.com.br/artigos/30179/observacoes-prefaciais-a-lei-13-010-2014-lei-menino-bernardo

Presidência da República (Brasil). (2014). Lei n 13.010, de 26 de junho de 2014. Altera a Lei no 8.069, de 13 de julho de 1990 (Estatuto da Criança e do Adolescente), para estabelecer o direito da criança e do adolescente de serem educados e cuidados sem o uso de castigos físicos ou de tratamento cruel ou degradante, e altera a Lei n 9.394, de 20 de dezembro de 1996. Brasília: Autor. Recuperado de http://www.planalto.gov.br/ccivil_03/_ato2011-2014/2014/ lei/l13010.htm 
Ribeiro, F. B. (2016) A proibição legal de castigos físicos na infância: alguns contrastes entre Brasil, Uruguai e França. Desidades, 10(4), 19-29. Recuperado de http://pepsic.bvsalud.org/scielo.php?script=sci_arttext\&pid=S2318-92822016 $000100003 \& \operatorname{lng}=\mathrm{pt} \& \operatorname{lng}=\mathrm{pt}$

Ridings, L. E., Beasley, L. O., \& Silovsky, J. F. (2017). Consideration of risk and protective factors for families at risk for child maltreatment: an intervention approach. Journal of Family Violence, 32, 179-188. https://doi.org/10.1007/ s10896-016-9826-y

Rios, K. S. A., Williams, L. C. A., Schelini, P. W., Bazon, M. R., \& Pinon, E. A. (2013). Inventário de Potencial de Abuso Infantil - CAP: evidências de validade e precisão. Avaliação Psicológica, 12(1), 51-60. Recuperado de http://pepsic. bvsalud.org/pdf/avp/v12n1/v12n1a08.pdf

Rodriguez, C. M., Russa, M. B., \& Kircher, J. C. (2015). Analog assessment of frustration tolerance: association with selfreported child abuse risk and physiological reactvity. Child Abuse and Neglect, 46, 121-131. https://doi.org/10.1016/j. chiabu.2015.02.017

Santos, P. L., Bazon, M. R., \& Carvalho, A. M. P. (2017). Family Adaptability and Cohesion Evaluation Scale IV (FACES IV): brazilian adaptation. Avaliação Psicológica, 16(2), 120-127. https://doi.org/10.15689/AP.2017.1602.01

Santos, P. L., Bazon, M. R., Carvalho, A. M. P., Minetto, M. F., Crepaldi, M. A., \& Boing, E. (2013). FACES IV: Escala de Avaliação da Coesão e Adaptabilidade Familiar - Versão IV. Minneapolis: Life Innovations Inc.

Sherbourne, C. D., \& Stewart, A. L. (1991). The MOS social support survey. Social Science and Medicine, 32(6), 705-714. https://doi.org/10.1016/0277-9536(91)90150-B

St-Germain, A., Baudry, C., \& Bussières, E. (2016). Les strategies d'intervention offertes aux jeunes mères sont-elles efficacies pour prévenir la maltraitance envers leurs enfants? Revue de Psychoéducation, 45(2), 271-287. https://doi. org/10.7202/1039050ar

Taillieu, T. L., Afifi, T. O., Mota, N., Keyes, K. M., \& Sareen, J. (2015) Age, sex, and racial differences in harsh physical punishment: results from a nationally representative United States sample. Child Abuse and Neglect, 38, 1885-1894. https://doi.org/10.1016/j.chiabu.2014.10.020

Ward, C., Sanders, M. R., Gardner, F., Mikton, C., \& Dawes, A. (2016). Preventing child maltreatment in low and middle-income countries. Child Abuse and Neglect, 54, 97-107. https://doi.org/10.1016/j.chiabu.2015.11.002

Wong, W. C. W., Chen, W. C., Goggins, W. B., Tang, C. S., \& Leung, P. W. (2009) Individual, familial, and community determinants of child physical abuse among high-school students in China. Social Science and Medicine, 68(10), 1819-1825. https://doi.org/10.1016/jsoscmed.2009.03.001

World Health Organization. (2016). Inspire: seven strategies for ending violence against children. Geneva: Author. https:// apps.who.int/iris/bitstream/handle/10665/207717/9789241565356-eng.pdf;jsessionid=E7BAA7EA68493A32128 1B5CC3322F89F? sequence $=1$

Received: July 17, 2019

Final version: June 10, 2020

Approved: July 13, 2020 